\title{
The International People's College at Elsinore
}

\author{
By Peter Manniche
}

My experiences while from 1921 to 1954 I was the principal of the International People's College at Elsinore may be summed up by the following observations:

1) However much the individuals may differ within a nation, there are certain reactions that may be characterized as national since they distinguish a comparatively large number within one nation from that of another.

2) The development of national fellowship is of vital importance. Grundtvig's experience that "light without warmth is the torment of hell", no doubt will prove a basic and generally acceptable argument for the existence of families, working groups and nations. Feelings must be attached to something concrete. Besides, the power of interpreting life's events can best be utilized in a circle small enough to make it possible to discern the right relationship between causes and effects of human conduct.

3) That the fundamental law of any national fellowship must be one which makes this a basis for supernationalism, a regard for all humanity.

4) Without common subordination to such humanitarianism nations will inevitably clash, and a few, and generally accepted laws backed by authority will probably be as necessary for the world at large as they are for a small international school society such as ours in which harmony and peace between the different nationalities would not have prevailed for any length of time, unless certain rules of regular work and an appreciation of constructive mutual intercourse were maintained.

5) Some great organizing geniuses with a vast field of vision 
may dare work out whole programmes of future operations for the testing of those whom they request to lend their support. As for me I would not dare do this, though of course I could not help visualizing plans ahead to meet new and particular circumstances. I learned to wait - as Quakers do, when they trust their "inner light" - for God's help and enlightenment which surpasses human understanding. I stumbled along, feeling my way forward, but those collaborators I met left behind them a vast store of affecting memories.

It was from the Danish folk high school that I obtained the idea of an international people's college. I had no desire to emphasize the virtues of the Danes above those of other peoples. Indeed I knew that we need to learn much from the intellectual, ethical and religious accomplishments of other countries. But also Denmark has contributions. A particular one is the fact that here as in the other Scandinavian countries Bishop Grundtvig's words that in a truly rich country "few have too much and still fewer too little", have come to express a widely shared ideal. Once the Nordic peoples lived in mutual enmity under the constant threat of war with the resulting difficulties in facing internal economic and social problems. They have now for some two centuries been living together as peaceful neighbours. This sense of unity developed a total mental state, an entire sense of consciousness, the limits of which cannot be determined. If the peoples of the world could be induced to intermix as the Scandinavian peoples did, war might ultimately be precluded. It would not be a vague dream that just as the Scandinavian folk high schools had helped to create the national fellowship that supplied a cultural basis for the development of such democracy common to all Scandinavian countries, an international folk high school might be able to participate in the creation of an international human fellowship and democracy.

It was, however, not till 1916, as the result of a religious inspiration, while I served in the Danish army, that I used a three months' furlough to go to England for guidance and support of my dreams. The whole country was at that time concentrated on the war and feeling was hot against Germany and the Kaiser. But although feeling was tense, good humour and faith in future good-will and cooperation existed, which bombs had not been able to extinguish. English Quakers and university professors at Oxford and elsewhere 
as well as politicians of different parties, employers and leaders of cooperative and labour organisations assisted me, and I obtained similar support in my own country when I returned.

Our records show, that during the 34 years I was the principal, a total of about 9000 students had attended the short vacation courses and some 5000 the regular winter course of five months and summer course of three months. Some 44 nations had been represented. However, whilst about three fourths of the vacation course students came from abroad, the proportion of foreign students at the long courses was about one third. During the principalship of my successors, Vagn Fenger (1954-69) and Børge Mølgaard Madsen, the number of nations represented has increased to about 55 and there is a majority of foreign students both during the winter and summer terms, the length of each being now $4^{1 / 2}$ months.

The growth of the College cannot but seem to me a true miracle, for there had been no organisation to promote its interests or provide financial guarantees. A. C. Meyer, the socialist M. P. representing the poor neighbourhood of Copenhagen in which the Christian Student Settlement, where I had been working, was situated, was one of the few Danes, to whom I first confided my idea of the College. It was he who, together with Dr. L. Moltesen, a liberal M. P. and State Supervisor of the folk high schools, and my own professors, Otto Jespersen and Edvard Lehmann, helped me to get the visa for England. It was also he, who wrote a song for the students, the first of these being a group of artisans and industrial workers, who turned up from the Settlement and its excrescense, "The Folk High School and Study Circle Union of Copenhagen", the principal of which I had become.

This first student group was willing to work five hours a day for their board, lodging and tuition (three hours a day). It is true of life in any community, small or large, that it is the will to surmount difficulties that uplifts the mind and creates goodnatured humour. For the special benefit of such readers as are interested in the start of folk high schools in their own countries, I will give a short account of our financial resources and the buoyancy with which we tried to get on even with the difficulties the scarcity of them involved.

Kirsten Svelmøe Thomsen, editor of the journal "Fellowship of Reconciliation", Cai Hegermann Lindencrone, chairman of our 
committee, the professors Harald Høffding, Valdemar Ammundsen, Niels Bøgholm, and all the professors in the faculties of humanities and political economy whom I approached sponsored a public appeal for support. In 1921 we had collected $65,000 \mathrm{kr}$. to cover disbursement for an old farm of five acres of land near Elsinore to change it into a school, restore the buildings and equip them with second-hand furniture, and to cover other expenses during the first school term. The large stable was turned into a lecture hall which served its purpose well until later a generous man gave us a donation for a fine new one. We leased 45 acres of land for farming for a period of five years.

During the first two years students came from Austria, England, USA and the Scandinavian countries. They came from both town and country, from farms, workshops, factories and offices, from universities, folk high schools or commercial schools. Some had no previous training over and above the elementary school. During the first short vacation course most of the students were teachers.

A pioneer spirit was created, which during the following years was not extinct. Songs and music, the most international language, manual work and the study of language and social conditions in different countries were able to keep the students happily occupied, and the work for a common cause kept them together in a good fellowship.

The tension in the ex-soldiers which years of war had stirred up, seemed to disappear in the light of humorous happenings. I yield to the impulse of jotting down just a few of them.

Robert Müller was an ex-officer of the Austrian army. His face was full of scars which were his pride, and he tended to bully his two fellow countrymen when they worked in the fields, he himself being a very eager and conscientious worker. Gahler, one of them, was not an expert in the turnip field, but excelled in another one, for he was primarily a scholar and bore no other marks of distinction than a conspicuous pair of spectacles. So he got the easier job of leading our only and beloved cow every morning to a distant field and back again in the evening. He and the cow walked slowly and harmoniously together, each stopping patiently when the other did, the cow to ruminate and the student to digest his Greek grammar. Citizens of Elsinore have later told me of the amusing figure he cut, when they met him on their morning walk. 
This spectacled young man with a book in one hand and a tether in the other almost became a symbol of what the school stood for, the spirit of co-operation and the equal balance between the work of the hand and the mind.

Herbert Jacobsen, a Danish metal worker, did our cooking in the beginning until he was succeeded in the work by Miss Aamand who probably saved us from premature death from constipation, since his menu was limited to only two items, coffee and beef. Still, when Jacobsen's two brothers and his cousin later signed up as I. P. C. students, the only recollections we had of the red-haired smith and his big saucepan were happy ones.

Generally speaking, time passed quickly and smoothly so long as we were happily engaged - as we usually were - in some kind of work. Folmer Dam, a graduate of the Royal Agricultural College, inspired interest in the theory and practice of farming, and the enthusiasm for the study of languages was boundless. A Copenhagen tobacco worker, who had the go-ahead spirit that is characteristic of many city dwellers, was a beginner in the English language, but insisted on attending lectures for the advanced group. When asked what he got out of this he once answered: "I understood most of it. He was talking about French bacon". Actually the subject of the lecture was Francis Bacon, the English philosopher.

My fellow teachers Rennie Smith and Poul Hansen served the College for respectively one and five years and did not lose contact with us when later they both became M. P.s. The Swede Emil Lennings, the German August Henning and the Englishman Percy Wait served it almost as long as I did. I would like to mention and praise the many men and women who helped the College year after year as teachers, student representatives and committee members at home and abroad, but it would cover several pages. I was always particularly dependent on the help of others.

In the second and following years the teaching became more systematic and a curriculum developed which was determined partly by the tradition of the Grundtvigian folk high school, partly by the international character of the College. The Danish folk high school tradition when I. P. C. was started may be characterized as personal in method, individualistic in educational principle and religious-ethical in purpose. The same became true of the I. P. C. 
It was the personal contact between teacher and student and between the students themselves that helped to fuse the heterogeneous group into a living fellowship. The individualistic principle was equally important. The curriculum had as far as possible to be served à la carte. Though the Grundtvigian folk high school resulted in making better farmers, it primarily aimed at making better human beings. The conception of international brotherhood made I.P.C. likewise serve an ethical purpose. Young people cannot fully unfold themselves unless they are hopeful - also in their relationship to people different from themselves. One of the most important tasks of the I. P. C. should be to support them in this, to emphasize the positive sides of each nation and help them to learn from these, while keeping a certain amount of sound criticism, which is also characteristic of a sincere and alert youth.

Though generalization about so intricate a subject as national characteristics is fallible, the geographical environment and historical circumstances rather than innate genetic differences are no doubt somewhat responsible for such cultural differences between nations and races as do exist. Among the factors of influence there is, of course, the education which the nations provide for their children and youth. Here I just want to call attention to a few observations, with which I have dealt more fully in my books "Rural Development and the Changing Countries of the World" and "Denmark, a Social Laboratory", (Pergamon Press, Oxford).

While the Scandinavians proved to prefer the teacher to be the first among equals, many Germans showed a longing for authority and were willing to work heart and soul for a leader who could inspire them with an ideology, which to them could be a premise for further development. The Welsh were ready to argue but even more ready to sing. I have seldom met people who can work - and fight - so wholeheartedly for a cause as the Irish can. Most Scots are generous, but purposeful and discriminating in their generosity, which may be the reason for the reputation they have as misers. Typical Americans are also generous, but the trust they have in their own experience of prosperity can often make it difficult for them to comprehend the real needs of other peoples. If they do not obtain quick results of an idea, they tend to quit it for another, but their undulating currents of fateful conduct fortunately seem to fall back into the same riverbeds of pioneering 
exploration or pragmatic puritanism. The English are rooted in their own traditions which they cannot help bringing with them when going abroad. But they seldom wear their nationalism on their sleeves and do not leave other peoples defenceless against it. They are more interested in results than in ideas.

We did come up against conflicting ideologies during a few short periods, but the very fact that the students were so different proved to be an asset rather than a liability for the purpose of the College. Indeed, the final purpose of an education for international understanding is not just more knowledge, not only a wider horizon or a better judgment about good and evil in our moral jungle. It is that, but it is more than that. Grundtvig would say that education is transference of life through the spoken word, the "living word", expression of life that is extant at the moment. But even this definition is not wide enough. Education is also interpretation of life. We are not educated in the stormy wind of experiences, but in the quiet, when we think of the experiences we have had and try to interpret them in such a way that they can give us a view of life or at least a working hypothesis. Once in a while it is necessary to leave the mass and be alone with our conscience to avoid the straight-jacket of public opinion. However, we should not remain in isolation, but go back into fellowship with others in order to interpret our experiences together with them. The Danish folk high school has supplied the young people of Denmark with an opportunity for this intellectual orientation towards what personal experiences they have had themselves. In the international fellowship which is necessary today we must meet with persons not only from other countries but also from other races and social classes to share our experiences with them for control and guidance.

Youthful idealism was evident in most of the students, keen as they were on helping to bring about a better future after the destruction of the wars. It was practical pedagogy to concentrate thoughts on the good fruits of this idealism, even if the mutual influences in such a heterogeneous body might work more or less unconsciously.

Looking back I find in my mind a very long row of pictures of I. P. C. students and of people I met when lecturing abroad. I think of the humour and loyalty I very often found in the English 
students, the industry and rich emotional life of many Germans, their musical gifts, the stability of Canadian, Dutch and Swiss students and the tactfulness and desire for logical thinking and absolute values characteristic of the French mentality. I think of how much Western peoples could learn from the freedom from worry and wilful mirth of the Indians, the self-control and sense of duty of the Japanese, the trust in providence of the Arabs, the Russians' trust in living on the thought of fellowship, the keen intellect and energy of the Jews and the spontaneous cordiality of the Africans. I know that these generalizations hide essential truths, and some of the finest virtues can easily be transformed into their very opposites, swept away by a ferocious mass psychosis. But this is one of the reasons why an education for international understanding is very important just now.

How could the meeting together of so many different nations at the International People's College break the edge of the general harshness and make their intellectual and ethical orientation become, however slow, a leaven of a better world order?

It could not be on the lines of misconceived Darwinism allowing the stronger individuals or nations to use their strength to suppress the weaker, nor could it be on the lines of a misconceived religion that makes any nation God's chosen people. To such as are Christians it must be in the spirit of Him who taught us to use our talents to serve, not to dominate. What matters is that persons of different religions, or of no religion, use their talents realizing that each individual, nation or race has only particular, and therefore limited powers, and does not possess all the qualifications to lead the world. If there be ever the possibility of harmony in the international orchestra, each race must be allowed to play its own instrument. 